\title{
Rotifers of Portuguese reservoirs in river Tejo catchment: Relations with trophic state
}

\author{
C. Baião \& M. J. Boavida ${ }^{1}$
}

Dept. Biologia Animal and Centro de Biologia Ambiental, Faculdade de Ciências, Univ. Lisboa, Campo Grande C8.1749-016, Lisboa, Portugal. cbaiao@netcabo.pt, mjboavida@fc.ul.pt

1. To whom correspondence should be addressed

\begin{abstract}
Twelve portuguese reservoirs were investigated in 1995 and 1996. These reservoirs suffer from the influence of several human activities. As a consequence, several reservoirs in the Tejo River basin are progressing towards eutrophication. The rotifer community was analysed using a Cluster Analysis and a Canonical Correspondence Analysis (CCA). These analyses permitted the depiction different groups according to rotifer species distribution and abundance. These groups reflected, in general, differences of trophic state among reservoirs and seasonal variation. The results of the present study point to gradual responses of rotifer communities to eutrophication.
\end{abstract}

Keywords: rotifers, trophic state, Canonical Correspondence Analysis (CCA)

\section{RESUMEN}

Doce embalses portugueses fueron investigados en 1995 y 1996. Estos embalses se hallan bajo la influencia de varias actividades humanas. Como consecuencia, varios embalses de la cuenca del río Tajo están evolucionando hacia un estado de eutrofización. La comunidad de rotíferos fue analizada mediante un Análisis de Cluster y un Análisis de Correspondencias Canónicas (CCA). Estos análisis permitieron describir diferentes grupos según la distribución y abundancia de las especies de rotiferos. Estos grupos reflejaban, en general, diferencias en el estado trófico entre los embalses y variaciones estacionales. Los resultados del presente estudio apuntan a una respuesta gradual de las comunidades de rotiferos a la eutrofización.

Palabras clave: rotíferos, estado trófico, Análisis de Correspondencia Canónica (CCA)

\section{INTRODUCTION}

Rotifers constitute an important fraction of the zooplankton. Although usually unimportant in terms of biomass (Ruttner-Kolisko, 1974), rotifers play a major role in energy transfer and nutrient cycling (Park \& Marshall, 2000a; Wetzel, 2001).

In the past decades, several studies reported changes in plankton community structure along trophic gradients (e.g. Gulati, 1990; Lyche, 1990; Karabin \& Ejsmont-Karabin 1991; Caramujo \& Boavida, 2000; Yeppesen et al., 2000). Changes in crustacean zooplankton, such as decrease in diversity and density increase related to reservoir aging, are also reported in literature (e.g. Popp et al., 1996). Because of the reduced generation times of these organisms, changes in specific composition of the rotifer communities can be detected in short time studies, as they generally show a quick answer to alterations in their habitat (Attayde \& Bozelli, 1998). In fact, rotifer abundance, as well as species composition and distribution, often reflect the trophic status of lakes (Mäemets, 1983; Radwan \& Popiolek, 1989; Ejsmont-Karabin, 1995; Attayde \& Bozelli, 1998; Dungan et al., 2001, 2002). Rotifers' contributions to the zooplankton community may increase with eutrophication (Zankai, 1984; Park \& Marshall, 2000b). However, the use of rotifer species as indicators of environmental heterogeneity patterns in general, and as indicators of improving trophic state in particular, has 
been questioned several times (Beaver \& Crisman, 1990; Haberman, 1995; Attayde \& Bozelli, 1998, Dungan et al., 2001).

Rotifer studies in Portuguese reservoirs are sporadic and performed on an individual reservoir basis. There is a lack of studies integrating several reservoirs and describing the rotifer community variation among reservoirs.

The high climatic heterogeneity in the Tejo catchment area promotes the existence of different reservoir assemblages with respect to hydrologic characteristics (Armengol, 1980). In addition, land uses in this region are different from one place to another, leading to different anthropogenic influences on the reservoirs, in spite of the low population densities. Another sort of influences, such as agriculture runoff and (mostly treated) small industrial effluents, impounds on the reservoirs. Water quality of some of these reservoirs is affected by excess use of fertilizers in surrounding agricultural areas. This situation is more important in the south part of the Tejo catchment area, where agriculture pressure is high. All of these factors, together with reservoir age, result in different reservoir trophic states. In a study conducted from 1991 to 1993 , based on several chemical parameters, an increase in trophic states was reported in 7 of the 11 reservoirs studied (Boavida \& Marques, 1997). More recently, the Hydrological Plan elaborated by the Portuguese authorities for Tejo watershed (1999) refers that $78 \%$ of the reservoirs are in an advanced state of eutrophication.

The purpose of this study was to identify and report the occurrence of rotifer species in 12 Portuguese reservoirs of the Tejo river catchment area, in an attempt to establish a relationship between the rotifer community and trophic state. For this purpose, a Canonical Correspondence Analysis (CCA) was used.

\section{METHODS}

Zooplankton communities from 12 reservoirs of the Tejo river catchment area were analyzed. The Meimoa, Águeda, Idanha, Castelo do Bode,
Luzia, and Cabril reservoirs are located north to the main course of the Tejo river. Belver and Fratel are located in Tejo mainstream. The remaining reservoirs (Maranhão, Divor, Póvoa and Montargil) are located south to the main course of the Tejo river.

Samples (two replicates) were collected every 5 meters until the maximum reservoir depth was reached with a $2 \mathrm{~L}$ capacity van Dorn bottle and were filtered in situ through a $30 \mu \mathrm{m}$ mesh size net. Zooplankton data of each sampling date were averaged to obtain one value per date. Animals were anaesthetized with carbonated water and preserved in sugar saturated formaldehyde (final concentration $4 \%$ ). Sampling was carried out in 1995 (spring, summer and autumn) and 1996 (spring and summer). On each sampling date the temperature, dissolved oxygen concentration (DO), and Secchi disk depth were measured in situ. Rotifers were identified after Ruttner-Kolisko (1974) and Pontin (1978).

Chlorophyll $a$ (CHL $a$ ) concentrations were calculated from integrated samples composed of sub-samples taken at $5 \mathrm{~m}$ intervals from surface until either $15 \mathrm{~m}$ of depth or maximum reservoir depth was reached. Chlorophyll $a$ was extracted overnight in acetone.

Carlson's (1977) trophic state index (TSI) was calculated from CHL $a$. Secchi disk values were not included in the calculation of the transparency component of the index, since large amounts of sediments were washed into most of the reservoirs during the study period, increasing the inorganic turbidity of the water.

Shannon's Diversity Index and Evenness were calculated with rotifer data for each sampling date (Zar, 1999).

Cluster analysis was performed on the rotifers' density $[\log (\mathrm{x}+1)$ transformed] to identify whether distinct groups of species occurred within the reservoirs. The Manhattan dissimilarity measure and Ward's sum of squares clustering algorithm were used. These analyses were performed with the STATISTICA analyses package (1995).

The species abundance matrix was analyzed using Canonical Correspondence Analysis (CCA). CCA was performed on the average spe- 
cies composition data $[\log (\mathrm{x}+1)$ transformed]. Species occurring only once were not included in this analysis. Temperature and dissolved oxygen concentration profiles were averaged so that one value was obtained for each sampling date. It was believed that in doing so there would be little loss of information, since no parameter differed much with depth, and in this way there would be one value per date for CCA. Temperature, dissolved oxygen concentration, Secchi transparency, and Chl $a$ were all $\log (\mathrm{x}+1)$ transformed.

The CCA is widespread for freshwater data analysis because it is a direct gradient analysis, allowing one to directly relate the pattern of community variation to the pattern of environmental variation (Ter Braak \& Prentice, 1988). Furthermore, this analytical method forms a linear combination of environmental variables that maximally separates the niches of the species (Ter Braak \& Verdonsschot, 1995). This analysis leads to an ordination diagram that simultaneously displays (a) the main patterns of community variations, as far as these reflect environmental variation, and (b) the main pattern in the weighted average of each species with respect to the environmental variables (Ter Braak, 1986). The CCA was performed using CANOCO for Windows (version 4.0, 1998).
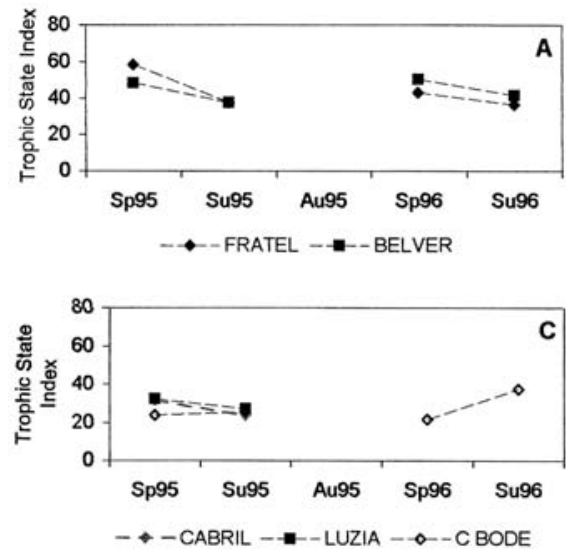

\section{RESULTS}

\section{Trophic state}

TSI computed from chlorophyll $a$ concentrations clearly shows the heterogeneity among these reservoirs related to trophic state (Fig. 1D). As expected from the high agricultural pressure, the trophic state index for reservoirs south to the Tejo river was higher than that of north reservoirs. The highest value $(\mathrm{TSI}=68)$ was recorded in Póvoa in the spring of 1995 and the lowest (TSI = 21) in Castelo do Bode in the spring of 1996. Three reservoirs, Montargil, Maranhão, and Póvoa, were classified as eutrophic (TSI >60), although special attention must be given to Póvoa, which in some situations can achieve a state close to hypertrophy. Divor was classified as meso-eutrophic (TSI: 50-60).

Fratel and Belver, both located in the Tejo River main course, were classified as mesotrophic to meso-eutrophic (TSI: 50-60). TSI for Fratel slightly decreased from 1995 to 1996. Idanha and Águeda exhibited the same variation regarding trophic state during the two years of study, in both oscillating between meso-eutrophic and eutrophic states (TSI >50). Meimoa was the reservoir with largest variation between
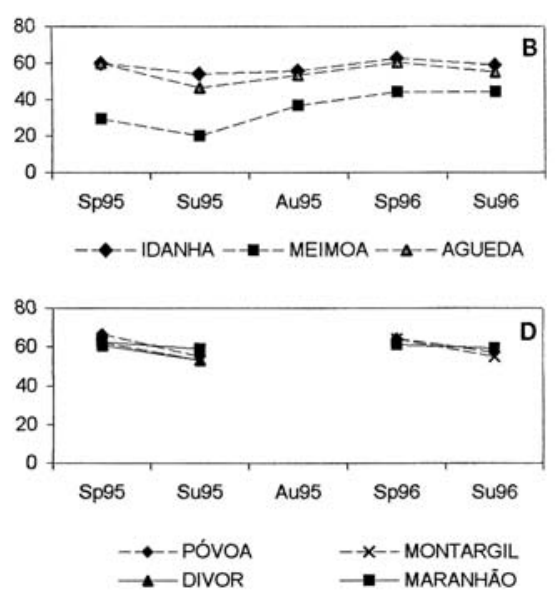

Figure 1. Trophic State Index (TSI from Chl $a$ ) of the different reservoirs. Fratel and Belver are located in the Tejo river mainstream; Póvoa, Montargil, Divor, and Maranhão are located south to the main course of the Tejo river; the remaining reservoirs are located north to the main course of the Tejo river.Índice de Estado Trófico (TSI de Chl a) de los diferentes embalses. Fratel y Belver se localizan en el curso principal del Tajo; Póvoa, Montargil, Divor y Maranhão se situan al sur del curso principal del Tajo; el resto de los embalses se localizan al norte del curso principal del Tajo. 

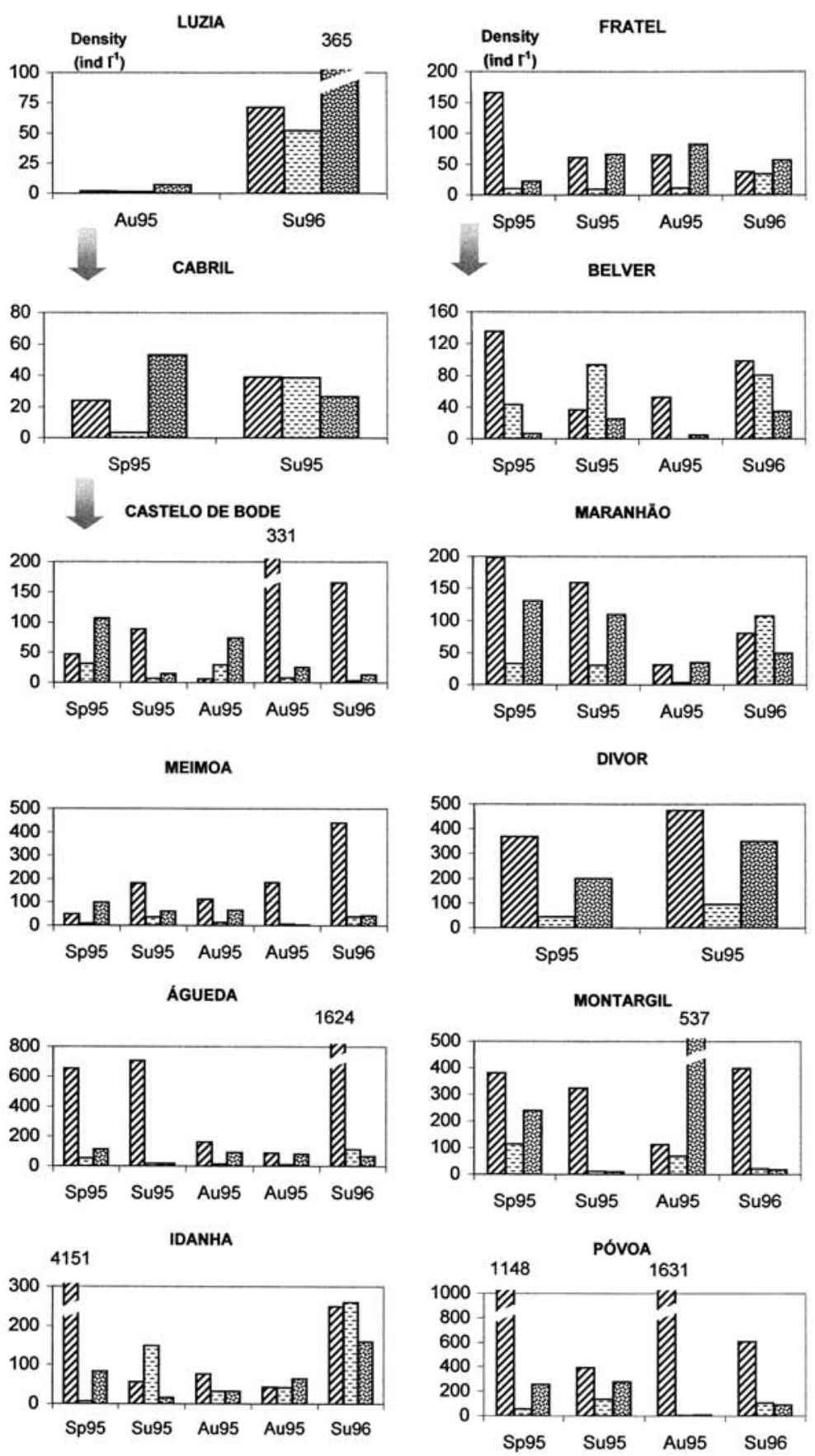

VROTIFERA GCLADOCERA

圆 COPEPODA

Figure 2. Seasonal zooplankton (copepods, cladocerans and rotifers) densities in each reservoir. Spring is represented as Sp, summer as $\mathrm{Su}$, and autumn as $\mathrm{Au}$. Arrows indicate water flow direction in chained reservoirs. Densidades estacionales de zooplankton (copépodos, cladóceros y rotíferos) en cada embalse. La primavera se representa como Sp, el verano como Su y el otoño como Au. Las flechas indican la dirección del agua en los embalses en cadena. 
1995 and 1996, ranging from an early state of mesotrophy in 1995 (TSI >30) to an advanced state of mesotrophy in 1996 (TSI <50). Luzia, Cabril, and Castelo do Bode were all oligotrophic (TSI <30) although during the summer of 1996 Castelo do Bode would better be classified as mesotrophic $(\mathrm{TSI}=37)$. With the exception

Table 1. Rotifer species found in 12 reservoirs belonging to the Tejo river basin (the right column represents abbreviations used in figures). Especies de rotiferos encontrados en 12 embalses de la cuenca del río Tejo (la columna de la derecha representa las abreviaciones utilizadas en las figuras).

\begin{tabular}{|c|c|}
\hline \multicolumn{2}{|l|}{ Asplanchna brightwelli } \\
\hline A. girodi & \\
\hline A. priodonta & A pri \\
\hline \multicolumn{2}{|l|}{ Anuraeopsis fissa } \\
\hline Brachionus angularis & B ang \\
\hline B. calyciflorus & $\mathrm{B}$ cal \\
\hline \multicolumn{2}{|l|}{ B. falcatus } \\
\hline B. urceolaris & $\mathrm{B}$ urc \\
\hline \multicolumn{2}{|l|}{ Cephalodella sp. } \\
\hline Collotheca mutabilis & $\mathrm{C}$ mut \\
\hline \multicolumn{2}{|l|}{ Colurella adriatica } \\
\hline \multicolumn{2}{|l|}{ Conochilus dossuarios } \\
\hline C. natans & $\mathrm{C}$ nat \\
\hline Epiphanes senta & Esen \\
\hline \multicolumn{2}{|l|}{ Euchlanis dilatata } \\
\hline \multicolumn{2}{|l|}{ E. luksiana } \\
\hline Filinia longiseta & F lon \\
\hline F. opoliensis & F opo \\
\hline \multicolumn{2}{|l|}{ Gastropus sp. } \\
\hline Hexarthra mira & $\mathrm{H}$ mir \\
\hline \multicolumn{2}{|l|}{ Keratella cochlearis } \\
\hline hispida and tecta & $\mathrm{K} \operatorname{coc}$ \\
\hline K. quadrata & $\mathrm{K}$ qua \\
\hline \multicolumn{2}{|l|}{ K. tropica } \\
\hline \multicolumn{2}{|l|}{ Lecane luna } \\
\hline \multicolumn{2}{|l|}{ Lepadella ovalis } \\
\hline \multicolumn{2}{|l|}{ Notholca squamula } \\
\hline Ploesoma hudsoni & Pl hud \\
\hline Pompholyx sulcata & Po sul \\
\hline Polyarthra dolichoptera & $P d o l$ \\
\hline P. euryptera & $P$ eur \\
\hline P. major & P maj \\
\hline P. vulgaris & P vul \\
\hline \multicolumn{2}{|l|}{ Synchaeta oblonga } \\
\hline S. pectinata & S pec \\
\hline Testudinella patina & T pat \\
\hline \multicolumn{2}{|l|}{ Trichocerca pusilla } \\
\hline Tr. similis & $\mathrm{T} \operatorname{sim}$ \\
\hline \multicolumn{2}{|l|}{ Tr. stylata } \\
\hline Tr. chatoni & Tcha \\
\hline
\end{tabular}

of Castelo do Bode, the highest values for TSI were recorded during spring at all reservoirs.

\section{Zooplankton community}

As expected, the highest zooplankton density (Fig. 2) was observed in the most productive reservoirs: Idanha (4151 ind/l, spring/95), Águeda (1623 ind/l, summer/95), and Póvoa (1456 ind/l, spring/96). The lowest zooplankton density was found in Luzia (10 ind/l, spring/95). With few exceptions, a dominance of rotifer species $(\geqslant 50 \%)$ was recorded in the most eutrophic reservoirs (Póvoa, Idanha, Águeda, Divor).

Dominance of the crustacean communities, in Luzia and Cabril, could reflect the low primary production of these reservoirs. A similar situation was found in Castelo do Bode only in 1995. In the Meimoa Reservoir a change in the structure of the zooplankton community was clearly seen as the evolution of trophic state occurred. In this reservoir the dominance by copepods was gradually substituted by dominance by rotifers.

Thirty-nine rotifer species were recorded in the Tejo river basin (Table 1). Most frequent and present in all reservoirs, at least in one sampling date, were Keratella cochlearis (one of the two forms, either tecta or hispida, the later much more frequent in all the reservoirs), P. dolichopte$r a$, and Asplanchna priodonta. Polyarthra vulgaris, absent in Luzia and Cabril, was frequent in all other reservoirs. Also present with relevant densities were Pompholyx sulcata, Synchaeta pectinata, and Conochilus natans (Fig. 3). Hexarthra mira was found in several reservoirs, yet never achieved a significant development.

Genus Trichocerca was frequently represented in almost all reservoirs, although in low densities, and was absent in less productive reservoirs (Luzia, Cabril and Castelo do Bode).

Genus Brachionus was present in the Divor Reservoir, where it achieved the highest density. In addition, $B$. calyciflorus was found in Póvoa, Maranhão, Belver and Fratel.

Ploesoma hudsoni was found only in Castelo de Bode, Luzia, and Cabril. Collotheca mutabilis also developed the most in these three reservoirs. 

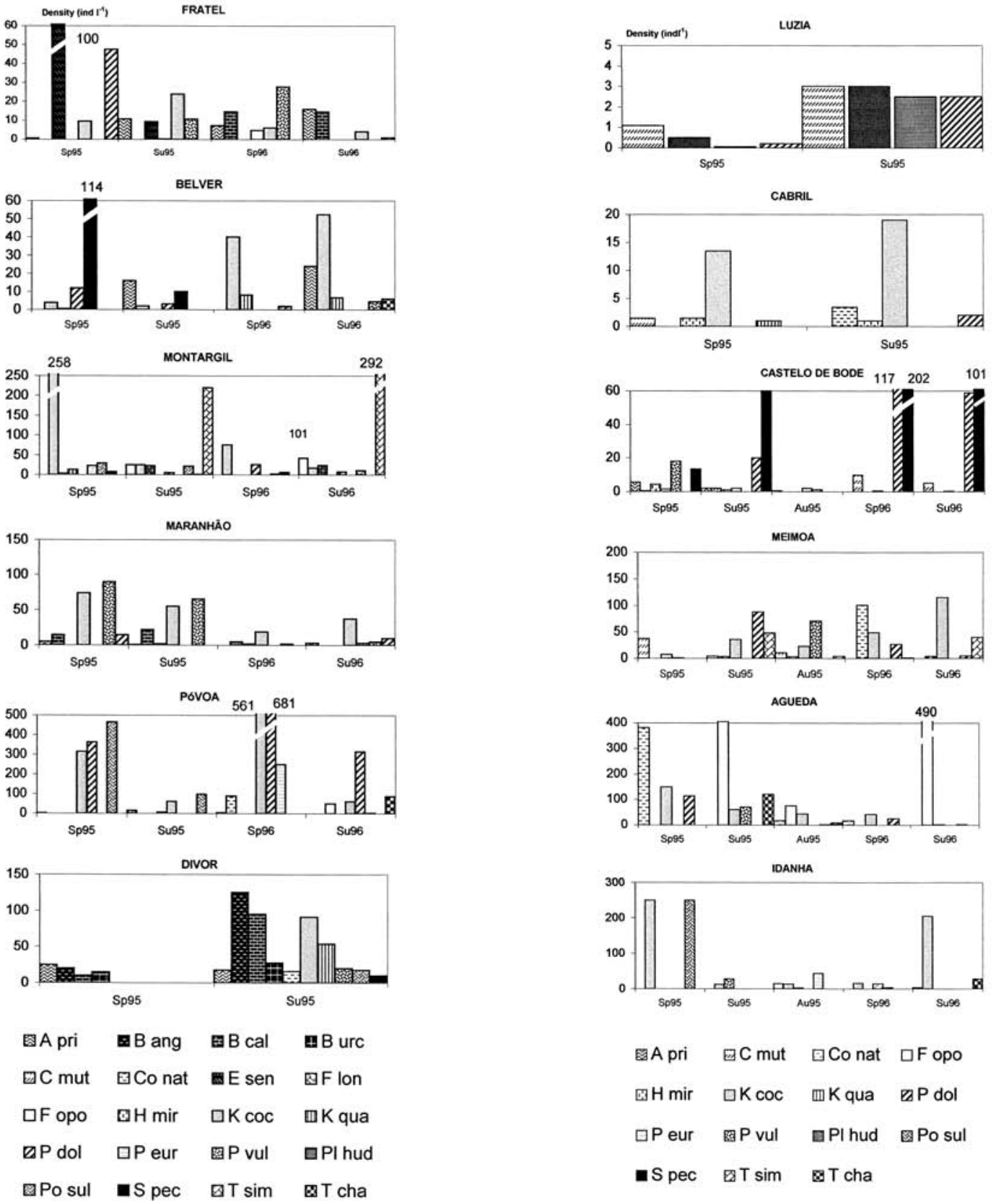

Figure 3. Seasonal rotifer densities in each reservoir (A pri-Asplanchna priodonta; B ang- Brachionus angularis; B cal- B. calyciflorus ; B urc- B. urceolaris; C mut- Collotheca mutabilis; Co nat- Conochilus natans; E sen- Epiphanes senta; F lon - Filinia longiseta; F opo- F. opoliensis; H mir- Hexarthra mira; K coc- Keratella cochlearis; K qua- K. quadrata; Pl hud- Ploesoma hudsoni; Po sul- Pompholyx sulcata; P dol- Polyarthra dolichoptera; P eur- P. euryptera; P vul- P. vulgaris; S pec- Synchaeta pectinata; T cha- Trichocerca chatoni; T sim- T. similis). Densidades estacionales de rotíferos en cada embalse (A pri- Asplanchna priodonta; $B$ ang- Brachionus angularis; $B$ cal- B. calyciflorus ; $B$ urc- B. urceolaris; $C$ mut- Collotheca mutabilis; Co nat- Conochilus natans; E sen- Epiphanes senta; $F$ lon - Filinia longiseta; $F$ opo- F. opoliensis; $H$ mir- Hexarthra mira; $K$ coc- Keratella cochlearis; $K$ quaK. quadrata; $P l$ hud- Ploesoma hudsoni; Po sul- Pompholyx sulcata; $P$ dol- Polyarthra dolichoptera; $P$ eur- P. euryptera; $P$ vulP. vulgaris; $S$ pec- Synchaeta pectinata; $T$ cha- Trichocerca chatoni; $T$ sim- T. similis). 
The lowest Diversity Index (Fig. 4) was recorded in Águeda $\left(\mathrm{H}^{\prime}=0.2\right.$, summer/96) and the highest in Divor $\left(\mathrm{H}^{\prime}=2\right.$, summer/96). Evenness ranged from 0.1 (Águeda, summer/96) to 0.9 (Castelo do Bode, autumn/95). No clear relationship with trophic state was observed in the variation of this index in the different reservoirs.
The variation of rotifer densities allowed for the grouping of reservoirs during the period studied. Six groups were formed under this analysis (Fig. 5). These groups reflected different rotifer communities among reservoirs, as well as seasonal variation. Group A refers to reservoirs where Filinia opoliensis was present
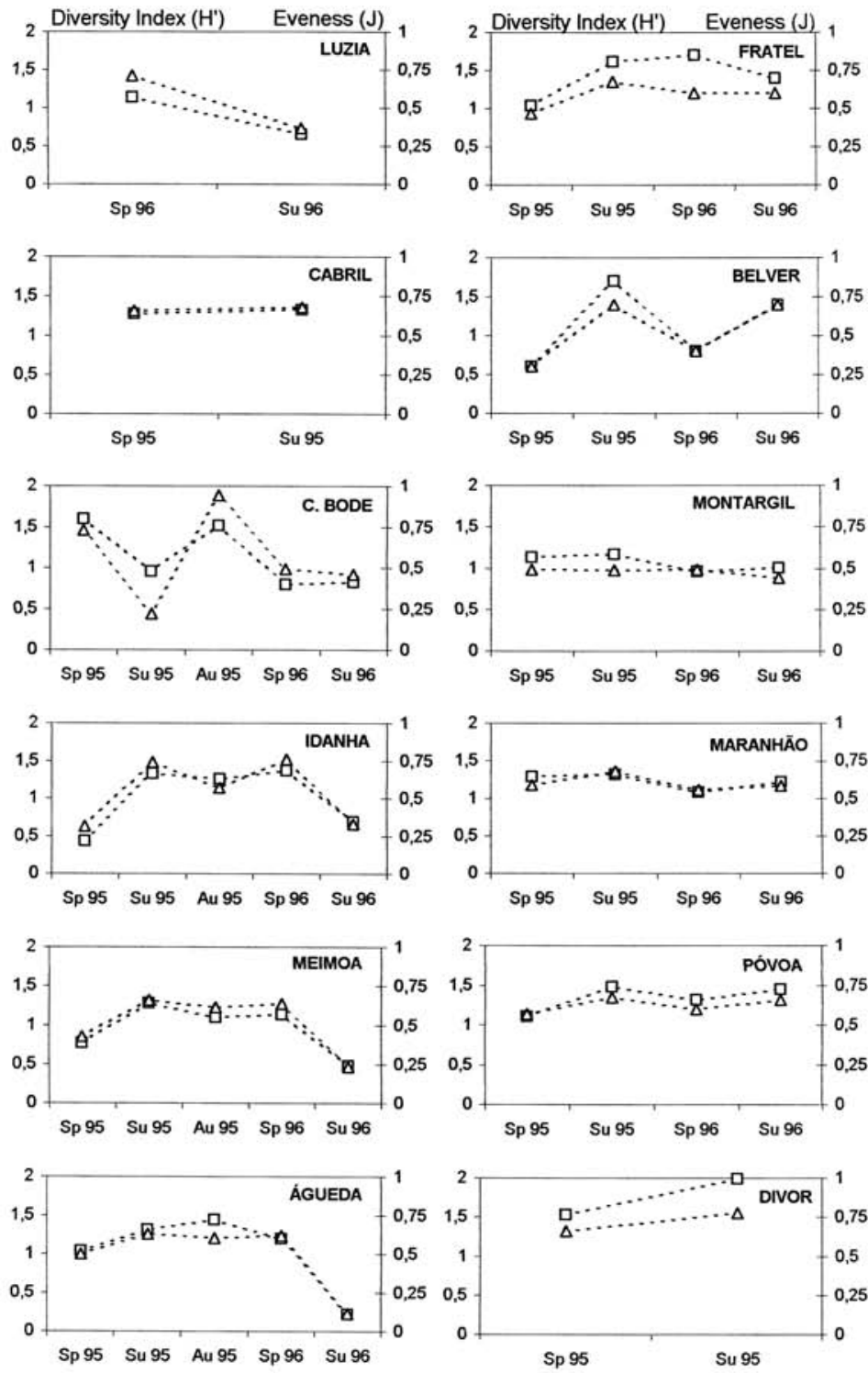

$\cdots \square \cdots$ Diversity $\cdots \Delta \cdots$ Eveness

Figure 4. Seasonal variation of Diversity Index ( $\left.\mathrm{H}^{\prime}\right)$ and Rarity $(\mathrm{J})$ in each reservoir. Variación estacional del Índice de Diversidad $\left(H^{\prime}\right)$ y Rareza $(J)$ en cada embalse. 


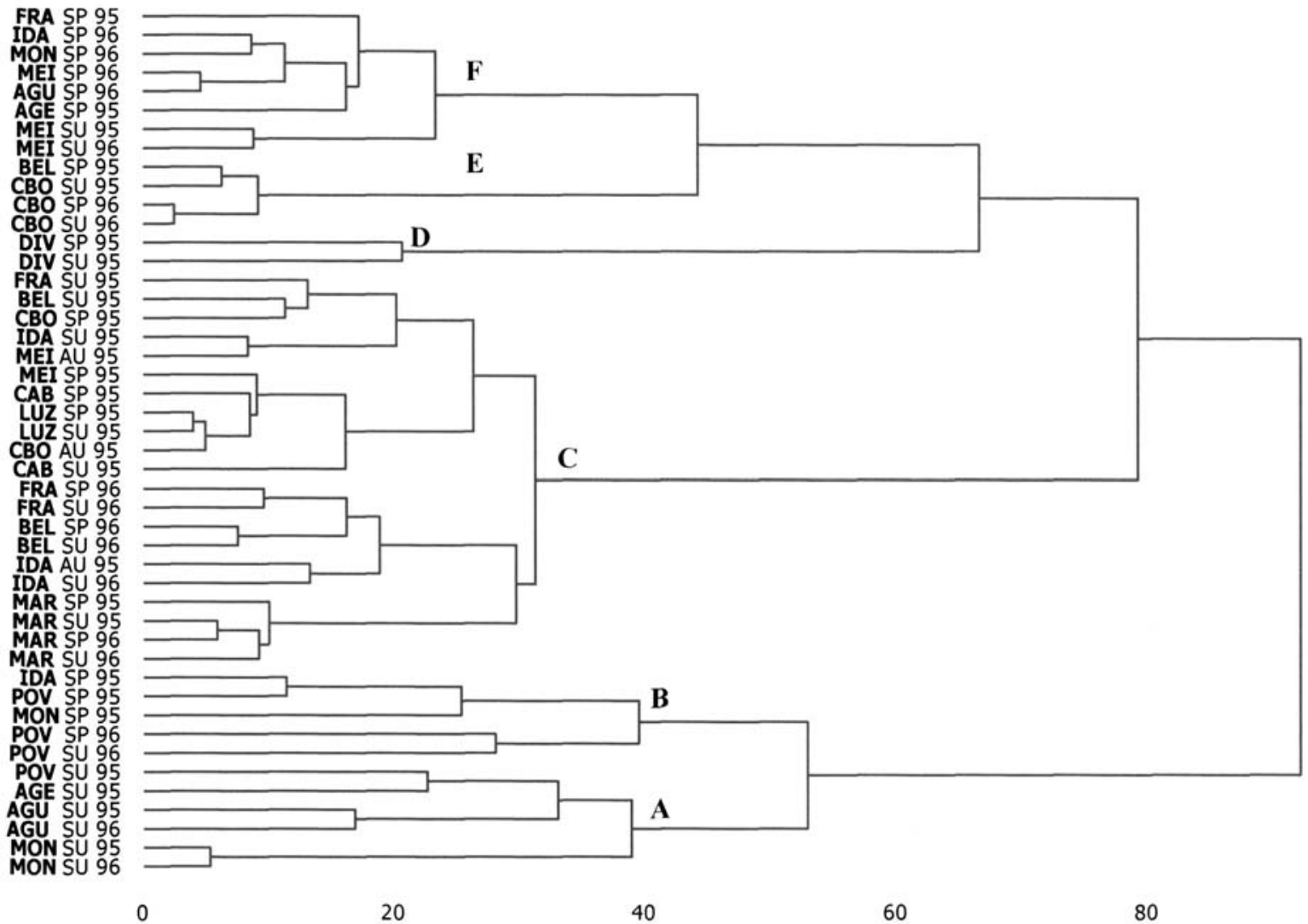

Figure 5. Dendrogram depicting group of reservoirs according to rotifer species density at each season. Dendrograma donde se diferencian los grupos de embalses según la densidad de las especies de rotíferos en cada estación.

in the summer. Trichocerca similis was important in the case of Montargil. Group B brings together reservoirs (spring data) where Pompholyx sulcata achieved maximum densities and where P. euryptera, P. dolichoptera, and T. chatoni were also observed. These two groups (A and B) are constituted of less deep reservoirs $(<13 \mathrm{~m})$ namely Idanha, Póvoa, Montargil, and Águeda. Group A corresponds to meso-eutrophic reservoirs. Group B corresponds to eutrophic reservoirs. Group C is very heterogeneous and a first assemblage can be observed where Asplanchna priodonta, $B$. calyciflorus, and K. quadrata were characteristic species (Maranhão, Idanha, Fratel and Belver are in this group). A second assemblage was formed by oligotrophic reservoirs (Castelo do Bode, Cabril, Luzia and Meimoa, the later only in 1995). In this group Collotheca mutabilis and Ploesoma hudsoni can be found. Group D accounts for Divor data, which corresponds, in general, to the highest diversity among the reservoirs. Genus Brachionus is represented in this reservoir by $B$. urceolaris and B. falcatus, in addition to B. calyciflorus, found in other reservoirs as well. Group E comprises Castelo do Bode data and is associated to the presence of $C$. mutabilis and $P$. dolichoptera. These species were also important in group F, and in this group C. natans, and T. similis were important as well.

From CCA, for all sampling reservoirs on each date, the combined eigen values of the two first axes of the ordination $(0.24$ and 0.15$)$ accounted for $66.7 \%$ of the total variance, of which $59 \%$ was explained by the environmental 

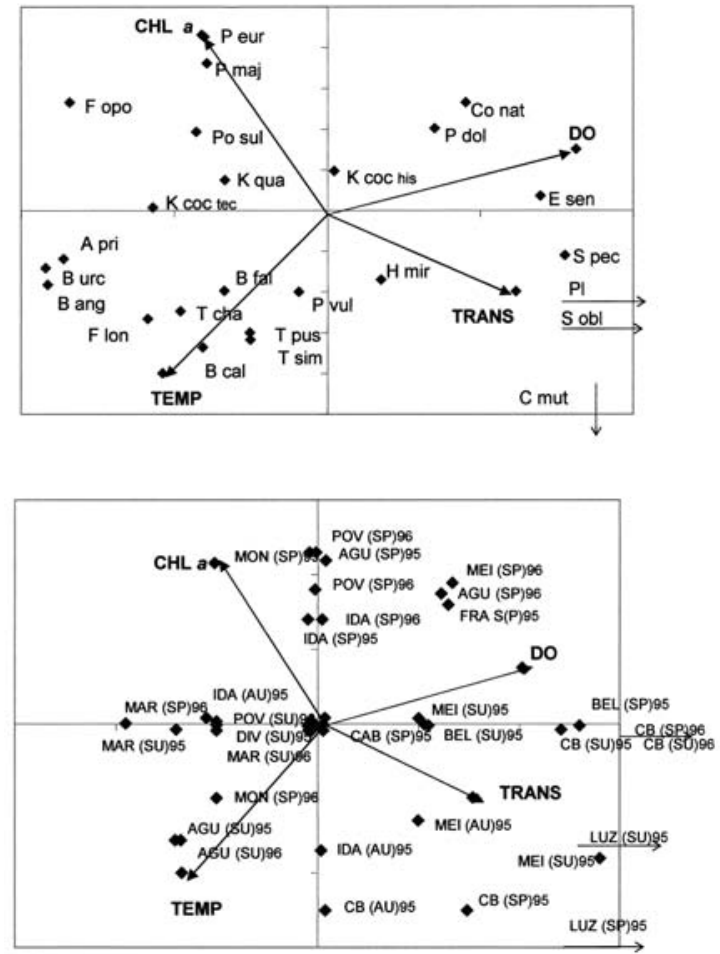

Figure 6. CCA ordination diagram with rotifer species (points) and environmental variables (arrows). The rotifer species represented follow Table 1 codes. Diagrama de ordenación CCA con las especies de rotíferos (puntos) y variables ambientales (flechas). Las especies de rotiferos representadas se indican con los códigos de la Tabla 1.

variables. The species-environment correlation coefficient for the first two axes was 0.78 .

The biplot (Fig. 6) of the matrices corresponding to the sampled reservoirs achieved by the two first axes generated by the CCA, suggests that Secchi disk transparency and dissolved oxygen (DO) were the important variables for the first axis (Table II). For the second axis, Chl $a$ is the major factor, but temperature was also strongly correlated with this axis. The projection of the species' points on the first axis showed that Filinia opoliensis, Brachionus sp., and Trichocerca sp. were more closely associated to high temperatures. High Chl $a$ concentrations were associated to P. euryptera, P. major, and Filinia longiseta. P. sulcata also showed a preference for highly productive conditions. On the other hand, and associated with high water
Table 2. Correlation coefficients between environmental variables and the first two CCA axes. Coeficientes de correlación entre las variables ambientales y los dos primeros ejes CCA.

\begin{tabular}{|c|c|c|c|c|}
\hline & \multicolumn{2}{|c|}{$\begin{array}{l}\text { CANONICAL } \\
\text { COEFICIENTS }\end{array}$} & \multicolumn{2}{|c|}{$\begin{array}{c}\text { INTER SET } \\
\text { CORRELATIONS }\end{array}$} \\
\hline & AX1 & $\mathrm{AX} 2$ & AX1 & $\mathrm{AX} 2$ \\
\hline TEMP & -0.4738 & -0.5618 & -0.4188 & -0.6218 \\
\hline DO & 0.5133 & 0.0020 & 0.6328 & 0.2345 \\
\hline TRANS & 0.1744 & -0.0998 & 0.4795 & -0.3083 \\
\hline Chl $a$ & -0.5387 & 0.5931 & -0.3181 & 0.6705 \\
\hline
\end{tabular}

transparency, Synchaeta pectinata, P. hudsoni, and $C$. mutabilis can be found. $C$. natans and $P$. dolichoptera seem to be more closely related to DO concentrations.

The projection of site scores shows a separation, reflecting the trophic state and seasonal variation. This corroborates, in a general way, the groups formed by cluster analysis. Thus, summer data seem to be more correlated with temperature, and this is the case for reservoirs with high trophic state and belonging to groups $\mathrm{A}, \mathrm{B}$ and $\mathrm{C}$ (from Cluster analysis), namely Águeda, Montargil, Póvoa, Divor, and Idanha. Correlated with high Chlorophyll $a$ concentrations are spring data from the same reservoirs, as are Fratel and Meimoa (1996) from groups B and F. Finally, correlated with high water transparency, are low production reservoirs Castelo do Bode and Luzia (spring and summer of 1995 and 1996), and Meimoa (1995).

\section{DISCUSSION}

Marques \& Boavida (1997) classified Luzia, Cabril, and C. Bode as mesotrophic, using the phosphorus component of Carlson's TSI, in 1992 and 1993. Using the chlorophyll component of the same index, Caramujo \& Boavida (2000) found these reservoirs to be oligotrophic in the period between 1993 and 1995. Although with some caution because of the different components of the index employed (Carlson, 1977), this could indicate an improvement in the trophic 
state of these reservoirs. Regarding the remaining reservoirs investigated in this study, only the rapid improvement in trophic state of the Meimoa Reservoir in 1996 deserves attention.

In general, analysis of zooplankton communities throughout the period studied reflects the dominance of rotifers in more productive systems. This has been described in the scientific literature (Bays \& Crisman, 1983; Haberman $1995)$ for the past decades and the Tejo reservoirs constitute no exception.

The Diversity Index did not show evidence of a relationship with trophic state. Although high richness (in number of species) was observed in highly productive lakes (Idanha, Póvoa and Maranhão), this was not accompanied by a correspondent increase in the Diversity Index (exception must be made for Divor and Póvoa), since at the same time blooms of rotifer species were observed, namely Pompholix sulcata and Filinia opoliensis (Idanha, spring of 1995) and Keratella cochlearis hispida (Águeda, summer of 1996). This finding is in agreement with the work of Attayde \& Bozelli (1998) who reporded the poor relation of this index with trophic state.

From cluster analysis it is possible to relate the evolution of trophic state to groups evidenced by this analysis. Associated to high trophic state reservoirs (Póvoa, Montargil, Idanha in spring) were Polyarthra euryptera and P. sulcata, species showing evidence of high correlation with Chlorophyll $a$ and known from scientific literature for their preference for highly eutrophic habitats. Filinia opoliensis is also common in summer samples from the same reservoirs. In reservoirs characterized by an intermediate trophic state we found Polyarthra vulgaris associated with $B$. calyciflorus, A. priodonta, and/or K. quadrata. In another cluster formed mainly by reservoirs located north to the main course of the Tejo river, a gradient in trophic state was revealed from mesotrophic reservoirs to eutrophic ones. This evolution is accompanied by changes in rotifer communities in which the presence of C. mutabilis and T. similis can be observed in mesotrophic reservoirs, C. natans in meso- eutrophic and eutrophic reservoirs, and only $P$. dolichoptera and K. cochlearis, either tecta or hispida, in eutrophic reservoirs.

The presence of $C$. mutabilis in mesotrophic reservoirs may suggest a transitional situation, since this species is characteristic of oligotrophic reservoirs (Luzia, Cabril and Castelo do Bode), along with Ploesoma, in the Tejo river basin.

Different groups reflect, in general, differences in trophic state among reservoirs, as well as seasonal variation. Yet, instead of discrimination of distinct groups as eutrophic, mesotrophic, and oligotrophic reservoirs, these results point to gradual and multiple responses of rotifer communities to eutrophication. Therefore, it may be concluded that, rather than one or two species related to a specific trophic state, there seems to be a response of the community as a whole to changing trophic states.

\section{ACKNOWLEDGEMENTS}

M. J. Caramujo, C. Crispim, and L. Figueira, assisted in sample collection. This study was partially supported by a doctoral grant (PRAXIS XXI/BD-3324/94) awarded to C. Baião by Fundação para a Ciência e a Tecnologia (Portugal).

\section{REFERENCES}

ARMENGOL, J. 1980. Colonización de los embalses españoles por crustáceos planctónicos y evolución de la estructura de sus comunidades. Oecologia Aquatica, 4: 45-70.

ATTAYDE, J. L. \& R. L. BOZELLI. 1998. Assessing the indicator properties of zooplankton assemblages to disturbance gradients by canonical correspondence analysis. Can . J. Aquat. Sci., 55: 1789-1797.

BAYS, J. S. \& A. P. CRISMAN. 1983. Zooplankton and trophic state relationships in Florida lakes. Can. J. Fish. Aquat. Sci., 40: 1813-1819.

BEAVER, J. R. \& T. L. CRISMAN. 1990. Use of microzooplankton as an early indicator of advancing cultural eutrophication. Verh. Internat. Verein Limnol., 24: 532-537. 
BOAVIDA, M. J. \& R. T. MARQUES. 1996. Total phosphorus as an indicator of trophic state of Portuguese reservoirs. Limnetica, 12: 31-37.

CARAMUJO, M. J. \& M. J. BOAVIDA. 2000. The crustacean communities of river Tagus reservoirs: Zooplankton structure as reservoir trophic state indicator. Limnetica, 18: 37-56.

CARLSON, R. E. 1977. A trophic state index for lakes. Limnol. Oceanogr., 22(2): 361-369.

DUGGAN, I. C., J. D. GREEN \& R. J. SHIEL. 2001. Distribution of rotifers in North Island, New Zealand, and their potential use as bioindicators of lake trophic state. Hydrobiologia, 446/447: 155-164.

DUGGAN, I. C., J. D. GREEN \& R. J. SHIEL. 2002. Distribution of rotifers in North Island, New Zealand lakes: Relationships to environmental and historical factors. Freshwat. Biol., 47: 195-206.

EJSMONT-KARABIN, J. 1995. Rotifer occurrence in relation to age, depth and trophic state of quarry lakes. Hydrobiologia, 313/314: 21-28.

GULATI, R. D. 1990. Zooplankton structure in the Loosdrecht lakes in relation to trophic status and recent restoration measures. Hydrobiologia, 191: 173-188.

HABERMAN, J. 1995. Estimation of the trophic state of Lake Vortsjarv on the basis of rotifers (Rotatoria). Proc. Estonian Acad. Sci. Biol., 44(3/4): 92-105.

KARABIN, A. \& J. EJSMONT-KARABIN. 1991. Structure, dynamics and distribution of zooplankton, and its many-years' changes in the Wigry Lake. Ekol. Pol., 39(3): 357-375.

LYCHE, A.1990. Cluster analysis of plankton community structure in 21 lakes along a gradient of trophy. Verh. Internat. Verein. Limnol., 24: 586591.

MÄEMETS, A. 1983. Rotifers as indicators of lake types in Estonia. Hydrobiologia, 104: 357-361.

MARQUES, R. T. \& M. J. BOAVIDA. 1997. Monitoring water quality in the Portuguese reservoirs of the river Tejo watershed. Verh. Internat. Verein. Limnol., 26: 740-744.

PARK, G. S. \& H. G. MARSHALL. 2000a. The trophic contributions of rotifers in tidal freshwater and estuarine habitats. Estuarine, Coastal and Shelf Science, 51: 729-742.

PARK, G. S. \& H. G. MARSHALL. 2000b. Estuarine relationships between zooplankton community structure and trophic gradients. J. Plankton Res., 22: 121-135.

PONTIN, R. M. 1978. A key to the freshwater planktonic and semi-planktonic Rotifera of the British isles. Freshwater Biological Association Scientific Publication $\mathrm{n}^{\circ} 38,178 \mathrm{pp}$.

POPP, A., K. D. HOAGLAND \& G. L. HERGENRADER. 1996. Zooplankton community response to reservoir aging. Hydrobiologia, 339: 13-21.

RADWAN, S. \& B. POPIOLEK. 1989. Percentage of rotifers in spring zooplankton in lakes of different trophy. Hydrobiologia, 186/187: 235-238.

RUTTNER-KOLISKO, A. 1974. Plankton rotifers: Biology and taxonomy. Die Binnengewässer, 26, Suppl., Schweizerbart, Sutttgart. 146 pp.

TER BRAAK, C. J. F. 1986. Canonical Correspondence Analysis: A new eigenvector technique for multivariate direct gradient analysis. Ecology, 67: 1167-1179.

TER BRAAK, C. J. F. \& I. C. PRENTICE. 1988. A theory of gradient analysis. Advances in Ecological Research, 18: 217-317.

TER BRAAK, C. J. F. \& P. F. M. VERDONSCHOT. 1995. Canonical correspondence analysis and related multivariate methods in aquatic ecology. Aquatic Sciences, 57: 255-289.

YEPPESEN, E., J. P. JENSEN, M. SØNDERGAARD, T. LAURIDSEN \& $\mathrm{F}$. LANDKILDEHUS. 2000. Trophic structure, species richness and biodiversity in Danish lakes: Changes along a phosphorus gradient. Freshw. Biol., 45: 201-218.

WETZEL, R. G. 2001. Limnology: Lake and River Ecosystems. $3^{\text {rd }}$ ed. Academic Press, 1006 pp.

ZÁNKAI, N. P. 1984. Predation of Cyclops vicinus (Copepoda: Cyclopoida) on small zooplankton animals in Lake Balaton (Hungary). Arch. Hydrobiol., 99(3): 360-378.

ZAR, J. H. 1999. Biostatistical Analysis. $4^{\text {th }}$ ed. Prentice-Hall Inc., USA, 663 pp. 
